\title{
Karnoprawna regulacja bezpieczeństwa publicznego
}

\section{Criminal law regulations of public safety}

\section{Streszczenie:}

Przestępstwa przeciwko bezpieczeństwu powszechnemu są głównie przestępstwami z narażenia dobra ${ }^{1}$. Przedmiotem ochrony jest życie ludzkie, zdrowie wielu osób czy mienie w wielkich rozmiarach. Do najczęściej popełnianych przestępstw z katalogu przestępstw przeciwko bezpieczeństwu powszechnemu należy spowodowanie pożaru i sprowadzenie niebezpieczeństwa zdarzenia zagrażającego wyżej wymienionym dobrom. Rośnie tendencja orzekania kar nieizolacyjnych ${ }^{2}$. Nadchodzące zmiany ustawodawcze mają podnieść wysokość kar dla tej grupy przestępstw³.

Słowa kluczowe: bezpieczeństwo publiczne, przestępstwo, prawo karne

\begin{abstract}
:
Crimes against public safety are mainly crimes involving exposure to danger. The subject of protection is human life, health of many people or property of large sizes. One of the most common crimes against public safety is causing a fire and bringing the danger of an event threatening the above-mentioned goods. The trend of adjudicating non-
\end{abstract}

${ }^{1}$ R. Stefański, Kodeks karny. Komentarz, Warszawa 2018 [dostęp: 10-07-2020]; L. Gardocki (red.), System Prawa Karnego Tom 8 Przestępstwa przeciwko państwu i dobrom zbiorowym, Warszawa 2018, s. 172, [dostęp: 10-07-2020].

2 „Skazania prawomocne z oskarżenia publicznego - dorośli - wg rodzajów przestępstw i wymiaru kary w l. 2008-2018” Informator Statystyczny Wymiaru Sprawiedliwości, https://isws.ms.gov.pl/pl/baza-statystyczna/opracowania-wieloletnie [dostęp: 9-07-2020].

3 The government bill amending the Act - The Penal Code and certain other acts (Parliamentary Print No. 3451). 
Artur Spirka - Karnoprawna regulacja bezpieczeństwa...

custodial penalties is growing. The upcoming legislative changes are expected to raise the penalties for this category of crimes.

Keywords: public safety, crime, criminal law

\section{Wprowadzenie}

Niniejszy artykuł ma na celu zbadanie zasadności zmian postulowanych przez ustawodawcę $\mathrm{w}$ zakresie przestępstw przeciwko bezpieczeństwu publicznemu. W pracy przedstawiono kształt obecnej karnoprawnej ochrony bezpieczeństwa publicznego poprzez analizę rozdziału XX kodeksu karnego 4 . Ukazany został również sposób realizacji owej ochrony poprzez analizę praktyki orzeczniczej w zakresie orzekanych kar na przestrzeni lat 2008-2018 oraz kierunek zmian, w jakim dąży ustawodawca. W pracy zastosowano metody badawcze: dogmatyczną oraz statystyczną.

\section{Dogmatyczna analiza przestępstw przeciwko bezpieczeństwu powszechnemu}

Bezpieczeństwo publiczne jest jednym z podstawowych warunków rozwoju ludzkości, zarówno w wymiarze personalnym (odnosząc się do indywidualnie oznaczonych podmiotów), jak i zbiorowym, obejmując całość życia społecznego. Na straży jego zapewnienia przez państwo pośrednio stoi prawo międzynarodowe poprzez liczne konwencje o prawach człowieka statuujące prawo do bezpieczeństwa osobistego, które jednak nie może być zrealizowane w sytuacji braku bezpieczeństwa publicznego. Bezpieczeństwo publiczne zabezpieczone jest również normami prawa krajowego poprzez nakazowe regulacje administracyjnoprawne, takie jak przebieg zgromadzeń, funkcjonowanie centrów zarządzenia kryzysowego czy działające w sposób pośredni wszelkiego rodzaju ewidencje. Zapewnienie bezpieczeństwa realizowane jest również poprzez normy prawa karnego, które wyznaczając

\footnotetext{
${ }^{4}$ Ustawa z dnia 6 czerwca 1997 r. Kodeks karny (Dz.U. 2019, poz. 1950).
} 
zakres penalizacji, pozwala zwalczać konkretne przypadki jego naruszeń.

Szeroko rozumiana karnoprawna regulacja bezpieczeństwa charakteryzuje się przedmiotem ochrony w postaci bezpieczeństwa. Realizacja tej ochrony następuje najczęściej poprzez główny przedmiot ochrony, jakim jest bezpieczeństwo. Istnieją jednak typy czynów zabronionych chroniące w sposób pośredni przed naruszeniami tego dobra prawnego, gdyż w procesie interpretacji danej normy karnoprawnej uwidacznia się dodatkowy (dalszy, uboczny) przedmiot ochrony w postaci bezpieczeństwa.

Przechodząc bezpośrednio do ochrony życia publicznego, można zauważyć, że już sama systematyka kodeksowa wskazuje kilka grup przepisów prawnych chroniących je. Należą do nich: rozdział XX przestępstwa przeciwko bezpieczeństwu powszechnemu, rozdział XXI przestępstwa przeciwko bezpieczeństwu w komunikacji, rozdział XXXII przestępstwa przeciwko porządkowi publicznemu. 0 ile problemu nie stanowi odnalezienie kryterium podziału na przestępstwa przeciwko bezpieczeństwu powszechnemu i przestępstwa przeciwko bezpieczeństwu w komunikacji (którym jest miejsce zajścia zdarzeń niebezpiecznych), o tyle wskazanie kryterium podziału na przestępstwa przeciwko bezpieczeństwu powszechnemu a porządkowi publicznemu nastręczać może nieco większy problem. Przybliżyć w tym miejscu należy różnicę zachodzącą między bezpieczeństwem a porządkiem, która prima facie leży w ciężarze gatunkowym czynu. Chcąc dokonać bardziej szczegółowej analizy tych pojęć, a brakuje takiej możliwości z powodu nieistnienia ich definicji legalnych, sięgnąć należy do wyników pracy doktryny i orzecznictwa. I tak, chcąc zdefiniować bezpieczeństwo, należy dokonać tego a contrario z definicji niebezpieczeństwa stanowiącej, iż jest to „powstanie sytuacji, która w drodze dalszych dynamicznych przekształceń może doprowadzić do powstania zmian w świecie realnym, które podlegają negatywnej ocenie z punktu widzenia społecznie akceptowanego wzorca"5. Bezpieczeństwem jest więc sytuacja,

\footnotetext{
5 G. Bogdan [w:] Kodeks karny. Komentarz, t. II, A. Zoll (red.), Kraków 2006, s. 43.
} 
Artur Spirka - Karnoprawna regulacja bezpieczeństwa...

w której nie zachodzą zmiany w świecie realnym, które podlegają negatywnej ocenie z punktu widzenia społecznie akceptowanego wzorca.

Z kolei definicję porządku publicznego wywieść należy z orzeczenia Sądu Najwyższego, opisującego stan zakłócenia porządku publicznego jako „stan, który w danym miejscu, czasie i okolicznościach, zgodnie z przyjętymi zwyczajami, obowiązującymi przepisami, uważa się za nienormalny. W obiektywnym odbiorze powszechnie akceptowanych zachowań, odczuwany jest jako utrudnienie lub uniemożliwienie ludziom normalnego zachowania się w miejscu dostępnym dla bliżej nieokreślonej liczby osób"6. Porządkiem publicznym jest więc stan, który w danym miejscu, czasie i okolicznościach, zgodnie z przyjętymi zwyczajami, obowiązującymi przepisami, odczuwany jest jako nieutrudniający oraz nieuniemożliwiający ludziom normalnego zachowania w miejscu dostępnym dla bliżej nieokreślonej liczby osób.

Po wyznaczeniu kryterium podziału na przestępstwa przeciwko bezpieczeństwu powszechnemu, przestępstwa przeciwko bezpieczeństwu w komunikacji oraz przestępstwa przeciwko porządkowi publicznemu przejść należy do omówienia tych pierwszych. Rozdział XX kodeksu karnego składa się z 11 jednostek redakcyjnych w postaci artykułów, z czego 4 z nich dotyczą zdarzeń niebezpiecznych, 3 - formy sprowadzenia zdarzenia niebezpiecznego (art. 163, 165 i $171 \mathrm{KK}$ ) oraz sprowadzenia bezpośredniego niebezpieczeństwa zdarzenia niebezpiecznego, 3 - dotyczące piractwa (porwanie statku, umieszczenie na nim substancji lub urządzenia niebezpiecznego oraz klasyczne piractwo), po jednym przepisie dotyczącym finansowania terroryzmu i przeszkadzania w akcji ratunkowej oraz 2 przepisy odnoszące się do karalności przygotowania i stosowania czynnego żalu wobec niektórych z powyższych przestępstw.

Rodzajowym przedmiotem ochrony jest bezpieczeństwo powszechne, które konkretyzuje się w postaci naruszenia bądź zagrożenia takich dóbr, jak życie ludzkie, zdrowie wielu osób czy mienie w wielkich rozmiarach (tu w znaczeniu przestrzennym, którego nie należy mylić

\footnotetext{
6 Wyrok Sądu Najwyższego z dnia 2 grudnia 1992 r., III KRN 189/92, Lex nr 162227.
} 
z mieniem wielkiej wartości z art. $115 \S 6 \mathrm{KK}$ ). Jak wskazuje A. Marek, niebezpieczeństwo jest zdarzeniem lub uruchomionym ciągiem przyczynowo-skutkowym stwarzającym zagrożenie dla życia, zdrowia wielu osób lub mienia w wielkich rozmiarach 7 . Zaznaczyć należy również, iż do karalności czynów, o których stanowią przepisy omawianego rozdziału, wymagane jest zagrożenie życia lub zdrowia wielu nieoznaczonych indywidualnie osób ${ }^{8}$. Jest to element wskazujący na powszechność zagrożenia bezpieczeństwa9.

Cechą widoczną prima facie jest to, iż przestępstwa w typie podstawowym są przestępstwami z zagrożenia, a nie naruszenia dobra ${ }^{10}$. Ustawodawca dokonał $\mathrm{w}$ ten sposób zabezpieczenia społeczeństwa przed samym wystąpieniem sytuacji zagrożenia. Przestępstwa $\mathrm{z}$ art. 163-172 KK są przestępstwami umyślnymi, w przypadku części z nich ustawodawca przewiduje typ uprzywilejowany $\mathrm{w}$ postaci działania nieumyślnego objętego łagodniejszą karą. Przestępstwa te mają również bardzo często typ kwalifikowany, który sprowadza się do wystąpienia skutku w postaci śmierci człowieka lub ciężkiego uszczerbku na zdrowiu, jest to też doskonały przykład występowania konstrukcji winy kombinowanej.

Kolejną cechą charakterystyczną przestępstw przeciwko bezpieczeństwu powszechnemu jest karalność przygotowania. Art. $16 \S 2 \mathrm{KK}$ stanowi, że przygotowanie jest karalne tylko wtedy, gdy ustawa tak stanowi. W przypadku rozdziału XX KK ustawodawca karalnością przygotowania objął 4 przestępstwa: sprowadzenie zagrożenia dla życia lub zdrowia wielu osób lub mienia w wielkich rozmiarach (art. $163 \mathrm{KK}$ ), sprowadzenie niebezpieczeństwa (art. $165 \mathrm{KK}$ ) oraz przejęcie kontroli nad statkiem (art. $166 \mathrm{KK}$ ) i przestępstwo umieszczenia na nim urzą-

7 A. Marek, V. Konarska-Wrzosek, Prawo karne, Warszawa 2016, s. 481-483.

${ }^{8}$ A. Grześkowiak, K. Wiak (red.) Kodeks karny. Komentarz, Warszawa 2018, Legalis/el. [dostęp: 9-07-2020].

${ }^{9}$ R. Stefański [w:] Kodeks karny, M. Filar (red.), Warszawa 2012, s. 754; A. Wąsek, R. Zawłocki (red.), Kodeks karny. Część szczególna. Tom I. Komentarz do artykułów 117221, Warszawa 2010, Legalis/el. [dostęp: 9-07-2020].

10 M. Królikowski, R. Zawłocki (red.), Kodeks karny. Część szczególna. Tom I. Komentarz do artykułów 117-221, Warszawa 2017, Legalis/el. [dostęp: 9-07-2020]. 
Artur Spirka - Karnoprawna regulacja bezpieczeństwa...

dzeń lub substancji niebezpiecznych (art. 167 KK). Regulacja przygotowania jest przejawem wysokiej wagi, jaką ustawodawca przywiązuje do kwestii bezpieczeństwa, dążąc do zapobieżenia popełnienia przestępstwa już na etapie jego przygotowania.

Wobec niektórych przestępstw przeciwko bezpieczeństwu powszechnemu ma zastosowanie instytucja czynnego żalu. Sprawca nie podlega karze za przestępstwa sprowadzenia bezpośredniego niebezpieczeństwa (art. $164 \mathrm{KK}$ ) oraz przestępstwa umieszczenia na statku urządzenia lub substancji niebezpiecznej (art. 167 KK), jeżeli uchylił grożące niebezpieczeństwo. Ten sam warunek musi spełnić sprawca, by zostać objęty nadzwyczajnym złagodzeniem kary za przestępstwa sprowadzenia zdarzenia niebezpiecznego (art. 163 i 165 KK zarówno w przypadku umyślności, jak i działania nieumyślnego) oraz przejęcia kontroli nad statkiem, sprowadzając przy tym bezpośrednie niebezpieczeństwo dla życia lub zdrowia wielu osób (art. 166§2 KK).

\section{Analiza praktyki orzeczniczej oraz rządowego projektu nowelizacji kodeksu karnego}

\subsection{Analiza praktyki orzeczniczej}

Przedstawione w Tabeli 1 dane statystyczne wskazują na brak tendencji spadkowych czy wzrostowych w zakresie ogólnej liczby skazań za przestępstwa przeciwko bezpieczeństwu powszechnemu. Zauważyć należy, że w roku 2016 doszło do wzrostu orzekania kar nieizolacyjnych, co przesądza o relewancji dyrektywy stosowania kar nieizolacyjnych. Odnotować należy również spadek orzekania kary pozbawienia wolności z zawieszeniem jej wykonania, która wcześniej stanowiła powyżej 75\% przypadków kary pozbawienia wolności, natomiast w latach 2016-2017 stosunek ten spadł do 60\%. 
Tabela 1. Skazania za przestępstwa przeciwko bezpieczeństwu publicznemu według orzekanych kar z uwzględnieniem zawieszenia wykonania kary

\begin{tabular}{|c|c|c|c|c|c|c|c|}
\hline \multirow[b]{3}{*}{ Lata } & \multicolumn{7}{|c|}{ Skazania } \\
\hline & \multirow[b]{2}{*}{ Ogółem } & \multicolumn{2}{|c|}{$\begin{array}{l}\text { Grzywna } \\
\text { samoistna }\end{array}$} & \multicolumn{2}{|c|}{$\begin{array}{l}\text { Ograniczenie } \\
\text { wolności }\end{array}$} & \multicolumn{2}{|c|}{$\begin{array}{l}\text { Pozbawienie } \\
\text { wolności }\end{array}$} \\
\hline & & $\frac{\Xi}{0}$ & 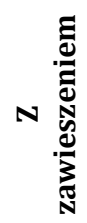 & $\frac{\Xi}{0}$ & 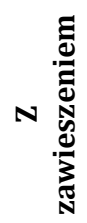 & $\frac{\Xi}{0}$ & 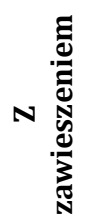 \\
\hline 2008 & 510 & 9 & 0 & 4 & 1 & 494 & 406 \\
\hline 2009 & 426 & 12 & 2 & 3 & 0 & 410 & 328 \\
\hline 2010 & 407 & 7 & 2 & 5 & 1 & 395 & 319 \\
\hline 2011 & 332 & 16 & 1 & 7 & 1 & 308 & 227 \\
\hline 2012 & 325 & 7 & 1 & 6 & 2 & 312 & 241 \\
\hline 2013 & 301 & 2 & 0 & 4 & 0 & 295 & 235 \\
\hline 2014 & 277 & 6 & 0 & 8 & 3 & 263 & 203 \\
\hline 2015 & 268 & 12 & 1 & 8 & 0 & 248 & 206 \\
\hline 2016 & 296 & 23 & 1 & 31 & 1 & 237 & 152 \\
\hline 2017 & 264 & 32 & 0 & 29 & 0 & 198 & 122 \\
\hline 2018 & 257 & 31 & 0 & 26 & 0 & 192 & 99 \\
\hline
\end{tabular}

Źródło: Opracowanie własne na podstawie danych z Informatora Statystycznego Wymiaru Sprawiedliwości

Dokonując głębszej analizy danych oraz wychodząc poza ramy przedstawione w powyższej tabeli, wskazać należy na częstotliwość skazań w zakresie poszczególnych typów czynów zabronionych, z których najczęstszym jest sprowadzenia zdarzenia, które zagraża życiu lub zdrowiu wielu osób albo mieniu w wielkich rozmiarach, mające postać pożaru. Kolejnym jest sprowadzenie bezpośredniego niebezpieczeństwa zdarzenia z art. $163 \mathrm{KK}$, a trzecim w kolejności nieumyślne sprowadzenia zdarzenia, które zagraża życiu lub zdrowiu wielu osób albo 
Artur Spirka - Karnoprawna regulacja bezpieczeństwa...

mieniu w wielkich rozmiarach. W przypadku tego ostatniego jego zaledwie trzecie miejsce wynikać może z możliwości stosowania warunkowego umorzenia postępowania karnego w stosunku do najlżejszych przypadków popełnienia tego przestępstwa ${ }^{11}$.

\subsection{Rządowy projekt nowelizacji kodeksu karnego ustawą z dnia 13 czerwca 2019 r. ${ }^{12}$}

Ustawa z dnia 13 czerwca 2019 r. o zmianie ustawy - Kodeks karny oraz niektórych innych ustaw wprowadza liczne zmiany, zarówno co do wprowadzenia nowych typów czynów zabronionych poprzez zmiany w katalogu kar, jak i wysokości kar za poszczególne przestępstwa. W zakresie przestępstw przeciwko bezpieczeństwu powszechnemu ma ona marginalne znaczenie, ponieważ nie zmienia znamion żadnego z zawartych w tym rozdziale typów czynów zabronionych, a jedynie w kilku przypadkach podnosi wysokość górnej granicy kary pozbawienia wolności z 12 lat do lat 15. W dwóch przypadkach jednak ma zastosowanie nowy katalog kar, który usuwa samoistnie występującą w nim karę 25 lat pozbawienia wolności, by wypełnić jej miejsce poprzez rozszerzenie górnej granicy terminowej kary pozbawienia wolności z 15 do 30 lat. Przypadkami tymi są: typ kwalifikowany przejęcia kontroli nad statkiem wodnym lub powietrznym (art. 166 §2 KK) oraz typ kwalifikowany drugiego stopnia (superkwalifikowany) tego samego przestępstwa (art. $166 \S 3 \mathrm{KK}$ ). Pierwszy z nich penalizujący sprowadzenie bezpośredniego niebezpieczeństwa dla życia i zdrowia wielu osób zagrożony jest karą pozbawienia wolności na czas nie krótszy od lat 3. Przy braku określenia górnej granicy ustawowego zagrożenia oznacza to, zgodnie z art. 37 KK, iż maksymalna wysokość kary pozbawienia wolności w tym przypadku wynosi 15 lat. Projekt nowelizacji sankcjonuje naruszenie tego przepisu karą od 3 do 20 lat pozbawienia wolności, wykorzystując do poniesienia górnej granicy ustawowego

\footnotetext{
11 „Skazania prawomocne...”, op. cit.

12 Rządowy projekt ustawy o zmianie ustawy - Kodeks karny oraz niektórych innych ustaw (Druk sejmowy nr 3451).
} 
zagrożenia nową konstrukcję kary pozbawienia wolności. Wspomniany wcześniej drugi przypadek wykorzystujący tę samą konstrukcję to typ kwalifikowany drugiego stopnia (superkwalifikowany), polegający na wystąpieniu skutku $\mathrm{w}$ postaci śmierci człowieka lub ciężkiego uszczerbku na zdrowiu wielu osób w wyniku następstwa wcześniej wspomnianego bezpośredniego niebezpieczeństwa dla życia i zdrowia wielu osób. Ustawodawca pragnie tutaj zrezygnować z terminowej kary pozbawienia wolności, której dolna granica wynosi 5 lat pozbawienia wolności oraz alternatywy w postaci kary 25 lat pozbawienia wolności na rzecz wspomnianej już wcześniej jednolitej kary pozbawienia wolności, którą w tym wypadku wyznaczył na okres od 5 do 25 lat pozbawienia wolności.

W zakresie potrzeby podniesienia kar za przestępstwa warto odwołać się do statystyki sądowej ${ }^{13} \mathrm{w}$ zakresie skazań w latach 2008-2018. W przypadku przestępstw z art. $163 \S 3 \mathrm{KK}, 165 \S 3 \mathrm{KK}, 165 \mathrm{a} \S 1 \mathrm{KK}$ i art. $166 \S 1$ KK zagrożonych obecnie karą od 2 do 12 lat pozbawienia wolności najwyższa orzeczona kara mieściła się w przedziale od 8 do 10 lat pozbawienia wolności, a wyrok tej treści zapadł zaledwie dwukrotnie w omawianym 10-letnim okresie. Na uwagę zasługuje również fakt, iż w tym samym okresie za przestępstwa z art. $165 \S 3 \mathrm{KK}$, 165a $\S 1 \mathrm{KK}$ i art. $166 \S 1 \mathrm{KK}$ skazano pięciokrotnie, a żadna $\mathrm{z}$ kar nie przekroczyła 5 lat pozbawienia wolności, natomiast za przestępstwo $\mathrm{z}$ art. 163 §3 KK (sprowadzenie zdarzenia niebezpiecznego, którego następstwem jest śmierć człowieka lub ciężki uszczerbek na zdrowiu wielu osób) zapadło 28 wyroków. W stosunku do art. $166 \S 2$ KK i art. $166 \S 3 \mathrm{KK}$ zagrożonych wyższymi karami (od 3 do 15 lat dla art. $166 \S 2 \mathrm{KK}$ i od 5 od 15 lat lub kara 25 lat pozbawienia wolności dla art. $166 \S 3 \mathrm{KK})$ statystyka sądowa milczy, albowiem w latach 2008-2018 nie zapadł żaden wyrok skazujący za te przestępstwa.

Z przedstawionej powyżej statystyki zdaje się płynąć wniosek o braku potrzeby podnoszenia wysokości górnej granicy ustawowego zagrożenia, albowiem sądy nie orzekały maksymalnej wysokości kary, co

\footnotetext{
13 „Skazania prawomocne..., op. cit.
} 
Artur Spirka - Karnoprawna regulacja bezpieczeństwa...

może świadczyć o właściwie zbilansowanym katalogu sankcji za naruszenie przepisów z rozdziału XX kodeksu karnego.

Do proponowanych zmian należy odnieść się krytycznie, bowiem są one wynikiem populizmu penalnego, polegającego na podnoszeniu wysokości kar, co w oczach społeczeństwa miałoby jakoby powodować refleksje u sprawców czynów zabronionych nad „opłacalnością” swej działalności. Ustawa ta również nie została podpisana przez Prezydenta, a skierowana do Trybunału Konstytucyjnego z wnioskiem o zbadanie zgodności jej postanowień z Konstytucją ${ }^{14}$.

\section{Podsumowanie}

Przestępstwa przeciwko bezpieczeństwu powszechnemu uregulowane w rozdziale XX Kodeksu karnego stanowią grupę przepisów wysokiej jakości prawnej, o czym świadczyć może brak sporów interpretacyjnych w doktrynie oraz dotychczasowy brak zainteresowania przez ustawodawcę. Statystyka orzecznicza również zdaje się potwierdzać skuteczność owej regulacji prawnej, notując ciągły spadek przestępczości tego rodzaju oraz brak potrzeby korzystania z maksymalnych sankcji oznaczonych w tych przepisach. Z powyższym jednak nie korespondują zmiany proponowane przez ustawodawcę, które w zakresie przestępstw przeciwko bezpieczeństwu powszechnemu zdają się być jedynie przykładem populizmu penalnego.

\section{Bibliografia:}

Filar M. (red.), Kodeks karny, Wyd. LexisNexis, Warszawa 2012.

Gardocki (red.), System Prawa Karnego Tom 8 Przestępstwa przeciwko państwu i dobrom zbiorowym, Wyd. C.H. Beck, Warszawa 2018.

14 Wniosek Prezydenta Rzeczypospolitej Polskiej z dnia 28 czerwca 2019 r. o zbadanie zgodności z Konstytucją ustawy z dnia 13 czerwca 2019 r. o zmianie ustawy Kodeks karny oraz niektórych innych ustaw, https://www.prezydent.pl/prawo/ ustawy/odeslane-do-tk/art,8,komunikat-w-zwiazku-ze-skierowaniem-przezprezydenta-rp-wniosku-do-trybunalu-konstytucyjnego.html [dostęp: 9-07-2020]. 
Gardocki L., Prawo karne, Wyd. C.H. Beck, Warszawa 2017.

Grześkowiak A., Wiak K.(red.) Kodeks karny. Komentarz, Wyd. C.H. Beck, Warszawa 2018.

Królikowski M., Zawłocki R. (red.), Kodeks karny. Część szczególna. Tom I. Komentarz do artykułów 117-221, Wyd. C.H. Beck, Warszawa 2017.

Królikowski M., Zawłocki R., Prawo karne, Wyd. C.H. Beck, Warszawa 2016.

Lis W. (red.) Przestępstwa przeciwko bezpieczeństwu państwa i bezpieczeństwu publicznemu, Wyd. KUL, Lublin 2017.

Marek A., Konarska-Wrzosek V., Prawo karne, Wyd. C.H. Beck, Warszawa 2016.

Rządowy projekt ustawy o zmianie ustawy - Kodeks karny oraz niektórych innych ustaw (Druk sejmowy nr 3451).

„Skazania prawomocne z oskarżenia publicznego - dorośli - wg rodzajów przestępstw i wymiaru kary w l. 2008-2018", Informator Statystyczny Wymiaru Sprawiedliwości, Internet [dostęp: 09-07-2020].

Stefański R., Kodeks karny. Komentarz, Wyd. C.H. Beck, Warszawa 2018.

The government bill amending the Act - The Penal Code and certain other acts (Parliamentary Print No. 3451).

Wąsek A., Zawłocki R.(red.), Kodeks karny. Część szczególna. Tom I. Komentarz do artykułów 117-221, Wyd. C.H. Beck, Warszawa 2010.

Wniosek Prezydenta Rzeczypospolitej Polskiej z dnia 28 czerwca 2019 r. o zbadanie zgodności z Konstytucją ustawy z dnia 13 czerwca 2019 r. o zmianie ustawy - Kodeks karny oraz niektórych innych ustaw, Internet [dostęp: 9-07-2020].

Wyrok Sądu Najwyższego z dnia 2 grudnia 1992 r., III KRN 189/92, Lex nr 162227.

Zoll A. (red.), Kodeks karny. Komentarz, t. II, Wyd. „Zakamycze”, Kraków 2006.

\section{Akty prawne:}

Ustawa z dnia 6 czerwca 1997 r. Kodeks karny (Dz.U. z 2019 r. poz. 1950). 